\title{
Archaeology, historical ecology and anthropogenic island ecosystems
}

THEMATIC SECTION

Humans and Island

Environments

\author{
TODD J. BRAJE*1, THOMAS P. LEPPARD ${ }^{2}$, SCOTT M. FITZPATRICK ${ }^{3}$ \\ AND JON M. ERLANDSON ${ }^{4}$ \\ ${ }^{1}$ Department of Anthropology, San Diego State University, San Diego, CA 92182-6040, USA ${ }^{2}$ McDonald \\ Institute for Archaeological Research, University of Cambridge, Domning Street, Cambridge CB2 3ER, UK, \\ ${ }^{3}$ Department of Anthropology, University of Oregon, Eugene, OR 97403, USA and ${ }^{4}$ Museum of Natural and \\ Cultural History, University of Oregon, Eugene, OR 97403-1224, USA
}

Date submitted: 30 June 2016; Date accepted: 15 March 2017; First published online 11 April 2017

\section{SUMMARY}

In the face of environmental uncertainty due to anthropogenic climate change, islands are at the front lines of global change, threatened by sea level rise, habitat alteration, extinctions and declining biodiversity. Islands also stand at the forefront of scientific study for understanding the deep history of human ecodynamics and to build sustainable future systems. We summarize the long history of human interactions with Polynesian, Mediterranean, Californian and Caribbean island ecosystems, documenting the effects of various waves of human settlement and socioeconomic systems, from hunter-gatherer-fishers, to agriculturalists, to globalized colonial interests. We identify degradation of island environments resulting from human activities, as well as cases of human management of resources to enhance productivity and create more sustainable systems. These case studies suggest that within a general global pattern of progressive island degradation, there was no single trajectory of human impact, but rather complex effects based on variable island physiographies, human subsistence strategies, population densities, technologies, sociopolitical organization and decision-making.

Keymords: human impacts, human-environmental interactions, Anthropocene

\section{INTRODUCTION}

For more than 150 years, beginning with Charles Darwin and Alfred Russel Wallace, islands have been central to investigations of evolution, biogeography, ecology and human-environmental interactions. Islands offer natural and historical scientists ecological systems to test theories about the past, present and future at scales that are smaller and more manageable than continental systems (Kirch 1997: 30). Studying the ecological history of islands can

*Correspondence: Dr Todd J. Braje email: tbraje@mail.sdsu.edu help elucidate the complex interplay between humans and environmental change, providing a framework for examining human influence and impacts in once-pristine environments (e.g. Erlandson \& Fitzpatrick 2006; Rick et al. 2013). Records of island responses to climatic fluctuations and human influence span millennia of land and seascape modification, introduction of biota, extinctions and other activities, which are often more clearly visible on island versus continental systems (Steadman \& Martin 2003; Wroe et al. 2006; Rick et al. 2013).

Even as scientists debate its genesis, the growing magnitude of human-driven environmental changes makes it increasingly clear that we now live in the Anthropocene, the geologic age of humans (e.g. Erlandson \& Braje 2013; Braje 2015; Lewis \& Maslin 2015; Ruddiman et al. 2015; Zalasiewicz et al. 2015; Waters et al. 2016). Most geoscientists argue that the 'age of humans' began sometime in the last 50 years, but many archaeologists and other historical scientists recognize the millennia-long, complex interplay between humans and their local, regional and global environments that shaped the Anthropocene. Today, many islands are threatened by accelerating environmental instability and uncertainty. Sea level rise, declining biodiversity, extinctions, landscape clearance and invasions by non-native species have fundamentally reshaped island ecosystems. Archaeological, palaeoenvironmental and historical ecological research, especially over the last two decades, demonstrates that anthropogenic alterations of terrestrial and marine ecosystems are not recent phenomena, but extend into deep antiquity (e.g. Jackson \& Hobbs 2009; Erlandson \& Rick 2010; Boivin et al. 2016). Evidence for human impacts on islands and archipelagos continues to rapidly accumulate, suggesting that the available data may represent the tip of the proverbial iceberg. Nonetheless, archaeology and other historical sciences now play a critical role in understanding the modern state of these ecosystems, predicting future outcomes and managing natural resources (Wolverton et al. 2016; Barnosky et al. 2017).

Research has produced cases of ecosystem degradation resulting from human activities and introductions (purposeful or accidental) of invasive plants and animals and cases of active management of resources to enhance productivity and 
Figure 1 Location map of the island regions discussed in the text (drafted by S.M. Fitzpatrick).

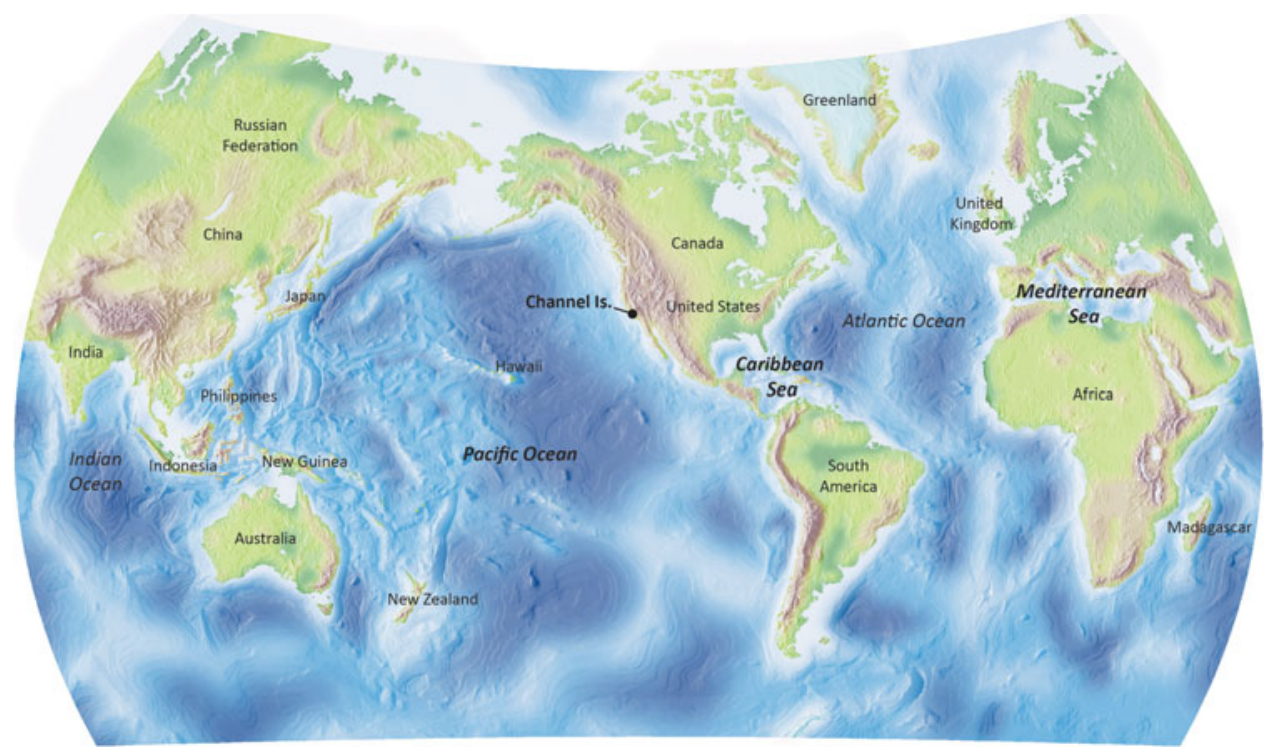

build long-term sustainable systems. These demonstrate the complexity of human-environmental interactions and offer perspectives on building future sustainable systems.

Most basically, historical ecology integrates ecology and historical sciences (Rick \& Lockwood 2013: 46) into a multifaceted discipline that is focused on the evolution of ecosystems, the effects of anthropogenic and natural changes and the relationship between humans and their environments. Archaeology is an increasingly essential component of historical ecology, offering important insights into past biotic abundances and distributions, the structure and function of ecosystems, system variability, harvest thresholds and desired future conditions (see Lotze et al. 2011; Braje \& Rick 2013: 310). While much historical ecological research comes from continental systems, island research has produced numerous examples of how understanding long-term humanenvironmental interactions and legacies of land and sea use can help guide future resource management.

We begin by reviewing the global history of human island colonization, then summarize changes to island systems after initial settlement by agriculturalists or sedentary foragers (or by hunter-gatherer-fishers, where relevant) and postfifteenth century Euro-American colonialism. We focus on four case studies, including the initial colonization of Near Oceania by Pleistocene hunter-gatherer-fishers and the later settlement of remote Pacific Islands by maritime agriculturalists; Mediterranean and Caribbean islands by hunter-gatherer-fishers, horticulturalists and agriculturalists; and California's Northern Channel Islands by hunter-gatherer-fishers (Fig. 1). Each case study explores how ancient people impacted island ecosystems, and how such impacts varied spatially, temporally and culturally. We explore the lessons that archaeological and other historical perspectives offer for the future management of island ecosystems.

These case studies include examples of colonization and human impacts on both oceanic and continental islands.
Differences in physiography - from the size and isolation of islands to their status as continental versus remote oceanic islands - may play a central role in predicting the structure and degree of human impacts. Since species richness increases with island area and decreases with island isolation, for example, a complex mix of factors influenced the degree of human forcing on island landscapes and seascapes through time. Some small, remote islands in the Pacific were quickly and irrevocably transformed by initial human colonization, then abandoned after human settlement became unsustainable. Processes of extinction, erosion and ecological transformation are often easier to decode and link to anthropogenic activities in smaller, remote islands than larger continental islands. These factors were especially influential during initial prehistoric colonizations. While we touch on these, future research can explore the often subtle (but at times dramatic) differences across islands in order to better understand how translocation, isolation and circumscription influenced ancient human-environmental ecodynamics.

\section{FROM COLONIZATION TO COLONIALISM}

Human colonization of many islands began early, with oceans and coastlines around the globe serving as pathways for the spread of anatomically modern humans (AMHs) (Erlandson 2010). Homo erectus colonized Flores and other Southeast Asian islands even earlier, by c. 1,000,000 years ago (Brumm et al. 2010), although whether this resulted from active seafaring or passive dispersal remains unknown (Dennell et al. 2014). Extensive evidence of island colonization by AMHs is found shortly after their spread out of Africa, however, perhaps along a coastal 'southern dispersal' corridor, with the colonization of Island Southeast Asia, Australia and New Guinea c. 50,000 years ago and western Melanesia and the Ryukyu Islands c. 35,000-40,000 years ago (Erlandson 2010; Fujita et al. 2016). Winds, currents and technology influenced the timing and nature of island colonization, 
and understanding these variables contributes to decoding the timing of human-island interactions. Variation in the subsistence practices of island explorers also resulted in very different impacts on island ecosystems. Colonization by hunter-gatherer-fishers generally resulted in less sweeping changes than colonization by agriculturalists, who tended to introduce a wider range of exotic (domesticated and wild) plants and animals, both intentionally and unintentionally. In many cases, humans created new anthropogenic ecologies, causing extinctions, trophic cascades and no-analogue ecological states.

Generally, anthropogenic changes resulting from initial human colonization pale in comparison to those from postcolonial contacts. European colonialism quickly overwhelmed island ecosystems (Mann 2011), which had already been influenced by indigenous peoples for centuries to millennia. Islands were integrated into global economies and transformed into agrarian plantation and production centres, long-distance trade and whaling stations and mercantile networks (Lightfoot et al. 2013). The scale and intensity of island transformations during this period far outpaced indigenous impacts, resulting in novel systems far removed from a 'natural' state. In the case studies below, we concentrate on broad patterns of human impacts and highlight the complexities of unravelling human impacts given physical variation in island size, location and isolation, as well as the nature of cultural adaptations.

\section{TRANSPORTED LANDSCAPES OF THE PACIFIC}

Around the world, human dispersal to islands often involved translocation of plants and animals. The human presence on the islands of Near Oceania as early as $c .32,000$ years ago was largely no different, although the number of Pleistocene sites is relatively small and the data ephemeral (Summerhayes et al. 2016). Late Pleistocene peoples who colonized islands within the circum-New Guinea Archipelago (CNG) - including the Moluccas, Sulawesi, Lesser Sundas, Bismarcks and Solomons - translocated animals between c. 20,000 and 3000 years ago, including the Pacific rat (Rattus exulans) and species of cuscus (family: Phalangeridae) and pademelon (Thylogale spp.) (e.g. Flannery et al. 1988; White 2004). Northern Sahul and the CNG also provide evidence for the exploitation and translocation of tropical plants such as the Galip nut (Canarium indicum) as long as 14,000 years ago (Summerhayes et al. 2016). Regarding extinctions and extirpations, research has focused on megafaunal disappearances across Sahul (Australia, New Guinea and Tasmania during the last glacial maximum (LGM)), with debates surrounding the human agency of such changes (e.g. Johnson et al. 2016; Saltré et al. 2016). For Pleistocene New Ireland, Steadman et al. (1999) noted bird taxa now absent on the Bismarcks and tentatively suggested human-driven extirpation. Given the clear evidence for human impacts on insular avifaunas elsewhere in the $\mathrm{Pa}$ cific, the Bismarck data may indicate that modern CNG biotas are the survivors of a Late Pleistocene disturbance event.
Human ecodynamics in Remote Oceania have operated on scales that are different from those of Near Oceania, structured in many ways by the immensity of the Pacific and the constraints isolation imposes on ecological and evolutionary organization. The relative spatial constriction of truly 'oceanic' islands (i.e. those with submarine volcanic origins) also renders Oceanic ecosystems highly sensitive to external influence.

Due to the sheer distance between landmasses, the settlement of Remote Oceania was late compared to our other case studies. First evidence for human settlement in the region comes from Lapita sites that stretch from the Reef/Santa Cruz Islands in the west through several major island groups, including Vanuatu, New Caledonia, Fiji and then eventually to Sāmoa and Tonga in the east. These population dispersals are generally contemporaneous with non-Lapita sites in the Marianas and Palau, which may date between c. 3400 and 2900 before present (BP) (see Fitzpatrick 2003; Clark et al. 2006; Sheppard et al. 2015). Long-distance migrations were enabled by outrigger and sailing technology (Irwin 1994). After nearly two millennia, eastward colonization occurred in pulses - possibly related to El Niño/Southern Oscillation cycling (Anderson et al. 2006; Montenegro et al. 2016) - into central and eastern Micronesia and central Polynesia and then, by $1200-800 \mathrm{BP}$, to Rapa Nui/Easter Island, Hawai'i and Aotearoa/New Zealand (Wilmshurst et al. 2011; Athens et al. 2014; Goodwin et al. 2014).

The natural biotas of Remote Oceania were comprised solely of successful long-distance colonists that evolved in isolation from continental taxa. The arrival of humans and associated species had transformative effects. Avifaunal extinctions are well documented (e.g. Steadman \& Martin 2003; Anderson 2009), driven by direct predation, habitat destruction and the introduction of predatory commensals such as dogs (Canis spp.) and the Pacific rat. Extirpation of endemic birds drove broader environmental change, especially affecting nutrient cycling (Kirch 1996). Long-term effects of these anthropogenic ecological reorganizations occurring as variations on a theme across Remote Oceania were exacerbated by land clearance and the introduction of successful domesticates. Initial Lapita colonization, and later post-Lapita movements, carried into island environments a suite of domesticates that changed little from 3500 to $800 \mathrm{BP}$, including taro (Colocasia esculenta), coconut (Cocos nucifera), breadfruit (Artocarpus altilis), yam (Dioscorea spp.), banana (Musa spp.), pigs (Sus spp.), dogs, chickens (Gallus spp.) and rats (e.g. Anderson 2009). Later, the sweet potato (Ipomoea batatas) was brought from South America into East Polynesia and became a major staple. These 'transported landscapes' were imposed on islands already experiencing post-colonization ecological trauma, resulting in similarly organized anthropogenic ecosystems. In their eastward expansion, colonizing humans also escaped some demographic constraints common to their homelands, including pathogens and their vectors not native to Remote Oceania, such as Plasmodium-bearing anopheline mosquitoes. 
This may have accelerated human population growth rates in Remote Oceania.

The human presence on previously unoccupied tropical islands implanted with successful horticultural systems also encouraged rapid growth among Pacific Islander populations. Demographic reconstructions are fraught with uncertainty, but a general pattern across Remote Oceania - clearly exemplified in Hawai'i with Dye and Komori's (1992) modelling of cumulative radiocarbon dates - involved steep initial $r$-type growth, with curves flattening as carrying capacity $(K)$ was approached (Kirch \& Rallu 2007). Combined with the geography of the Pacific, rapid population growth exerted profound pressure on Oceanic societies and fragile island ecosystems. Strategies to mitigate this pressure drove a series of socioecological and sociopolitical outcomes.

Subsistence intensification - a means of artificially increasing $K$ - is evident across Remote Oceania, frequently in the form of landscape modification. Terracing and hydrological management are conspicuous in the Hawaiian archipelago as well as the Marquesas, Society Islands and Sāmoa (e.g. Quintus et al. 2016). Divergence in horticultural intensification and management specific to the immediate environment is also apparent: wetland cultivation of Colocasia on O'ahu was matched by extensive dryland field systems on the arid portions of Hawai'i Island (e.g. Ladefoged et al. 2009). Attempts to control resources can also be seen in Hawaiian fishpond aquaculture. Such management efforts notwithstanding, the pulsing of colonization events into remote Polynesia may also be understood as responses to resource stress, combined with environmental conditions that facilitated eastward sailing (Anderson et al. 2006). This is underscored by oral histories that tie moments of social tension to long-distance voyages (Firth 1967: 24).

The supply problems posed by population growth (Bocquet-Appel 2011) and environmental limitations can be related to the apparent florescence of hierarchical forms of social organization across the Pacific during the last two millennia. The emergence of ranked societies relates to demands placed on circumscribed anthropogenic ecologies (Field et al. 2011). Along with driving colonization events, competition for resources is often framed ethnohistorically as an explanation for political change and consolidation (Kirch 2010: 77-124). Such competition is also implicated in Polynesian and Micronesian monumental architecture. Diverse megalithic traditions such as Yap's stone money (Fitzpatrick 2008) and Rapa Nui's huge moai statues are most readily interpreted as cases of competitive emulation and display (see also Kolb 2006).

The socioecological trauma of contact between Eurasian and Pacific populations has been exhaustively studied, and we cannot review the extent to which the arrival of Europeans (and their domesticates and commensals, parasites and viruses) radically altered the health and organization of indigenous Pacific societies (e.g. Kirch \& Rallu 2007). Rather, we emphasize the disruptive ecodynamic processes that accompanied colonization of the Pacific by European colonial interests. The arrival of exotic biota has driven pervasive biophysical cascades, affecting trophic systems, nutrient cycling, hydrology and soils (see D'Antonio et al. 2011; Chynoweth et al. 2013). In terms of conserving genetic diversity and mitigating the impacts of introduced biota, the Pacific situation is precarious (Jupiter et al. 2014).

Pacific Island biophysical systems have been (and continue to be) fundamentally transformed by human arrival and settlement. However, the physiographic organization of Remote Oceania - relatively minute patches separated by relatively massive expanses of ocean - is unmatched in its fragmentation, rendering the Pacific's endemic ecologies highly vulnerable to human colonization.

After colonization, emerging from the intensive management of productive anthropogenic landscapes, demographic growth and the existence of productivity thresholds, this fragmentation also drove the adoption of varied strategies, many of which resulted in highly inequitable political and social systems prior to and after European contact. Such political fragmentation, along with the pervasive nature of ecological changes over the millennia, also poses formidable challenges for restoration and conservation efforts across the Pacific.

\section{MEDITERRANEAN ISLANDS THROUGH DEEP HISTORY}

The environmental organization of the Mediterranean results from its unique physiographic and biotic structure, combined with deep historical anthropogenic processes. These have resulted in ecosystems with constituents that evolved under massive selective pressure from human activity.

For the Mediterranean islands, the antiquity of human settlement continues to be a contentious issue complicated by: (1) a hominin dispersal and occupation history that spans a million years or more; and (2) major palaeogeographic changes between glacials and interstadials over this time. Generally accepted models of Mediterranean human-island ecodynamics involve no significant occupation by archaic hominins and only sporadic exploitation by AMHs until the terminal Pleistocene or Early Holocene. Recent finds on Crete of possible Acheulean tools may challenge this (Runnels 2014), but the age and nature of these remain uncertain (Broodbank 2014). Leppard's (2014) survey of Pleistocene insular ecodynamics also found little evidence for substantial ecosystem changes potentially associated with colonization by archaic humans. There is little evidence for an anthropogenic influence on Mediterranean island ecosystems before the terminal Pleistocene (Palombo 2008); however, future surveys could reveal evidence for late Pleistocene colonization and occupation that is now largely obscured by rising sea levels since the LGM.

The apparent failure of archaic Homo to permanently settle most Mediterranean islands may be a function of the biogeographic constraints that sea gaps placed on early hominin dispersal. For early AMHs, most Mediterranean 
islands may have been relatively unattractive due to the comparatively lower productivity of marine waters (declining to the east), including low tidal amplitudes that limit intertidal productivity, and the generally depauperate nature of island terrestrial faunas. These environmental factors, combined with the calorific demands of mobile Upper Palaeolithic groups and the implications of these demands in relation to $K$ (gross scaling of $K$ with area and decreasing latitude) may have limited Upper Palaeolithic occupation (Cherry \& Leppard 2017). The greater diversity of Mesolithic subsistence strategies (see Sampson 1998) and the more expansive evidence for Mesolithic occupation support this model.

Endemism on Mediterranean islands declined catastrophically across the Pleistocene-Holocene boundary, with an $88.9 \%$ extinction rate (Alcover et al. 1998: 916). This is attributed, in part, to the sensitivity of Mediterranean Pleistocene biotas to climatic stress associated with the interstadial transition and surface area loss to sea level rise that affected taxa viability because of the relationship between area and food web complexity (Brose et al. 2004). The accelerating impacts of Epipalaeolithic, Mesolithic and Neolithic colonists were also driving forces in these extinctions. These impacts resulted from human hunting, as exemplified by possible mass-kill sites (e.g. Cypriot Aetokremnos; Knapp 2013: 52-59), and indirectly via the introduction of numerous domesticated plants and animals that competed with native biotas (e.g. the very late extinction of cave goats (Myotragus balearicus) on the Balearics; Bover et al. 2016). Some Southwest Asian xeric-tolerant domesticates (e.g. goats (Capra hircus), barley (Hordeum vulgare) and various pulses) carried westward by colonizing farmers between $c .10,000$ and $4500 \mathrm{BP}$ were preadapted to arid Mediterranean islands. Dependence on a more diverse suite of species circumvented the intrinsic trophic limitations of the island Mediterranean, making even very small and marginal island environments (e.g. Formentera and Pantelleria) viable for human settlement. The prevalence of more aridity-tolerant ovicaprids over cattle (Bos spp.) and pigs at sites on smaller, ecologically liminal islands lends corroborating evidence (Ramís 2014).

Elsewhere, the introduction of domesticated species into island ecosystems has been catastrophic (Chynoweth et al. 2013). In the Mediterranean, a relative paucity of data makes identifying and quantifying these impacts challenging, although there is a growing number of palynological studies with the time depth needed to help reconstruct ecodynamics throughout the Holocene (e.g. Sadori et al. 2008; Di Rita \& Melis 2013). Despite the difficulty in identifying basinwide patterns from local records, a Holocene reorganization of regional vegetation regimes is evident and at least partially anthropogenic. Nonetheless, a single clear signature of Neolithization is hard to grasp. Considering various pathways through which ovicaprids affect insular ecosystems, for example, we might expect that predation on preferred food sources would drive woodland fragmentation (via goat browse) in the short term and exert selective effects on preferred versus non-preferred species over evolutionary time.
These transformations would also affect other aspects of environmental organization (such as biogeochemical systems; e.g. soil nutrient cycling), as well as the trophic neighbours of such species, stimulating ecological cascades and driving evolutionary processes in associated species. The relatively woody morphologies of Mediterranean oaks (Quercus spp.), mastic (Pistacia lentiscus) and juniper (Juniperus phoenicea), with their retention of unpalatable secondary metabolites, may be explained, in part, as adaptions to millennia of selective pressure exerted by the herbivory of not only endemic, but also human-introduced ungulates. Mediterranean island floras have been subject to selective pressure from herbivores since their isolation after the Zanclean Flood, but the radical (and rapid) reorganization of trophic structures during Neolithization may have exerted selective pressure that was unusual in degree, if not in type (see Leppard \& Pilaar Birch 2016). One way or another, the Late Holocene biotic organization of the Mediterranean is generally disturbance adapted and resilient (Allen 2003; Butzer 2005).

Anthropogenic effects influenced both terrestrial and marine ecosystems ranging from coastal foraging to targeting species such as the bluefin tuna (Thunnus thynnus). Prehistoric impacts of such activities on prey demography may have been significant for some relatively sessile species, but probably minor for migratory species like tuna, although Holocene Atlantic bluefin stocks have declined substantially. Large-scale changes in environmental organization were also not limited to biota. Vegetation clearance and overgrazing associated with agropastoralism from c. 9000 to 4000 BP decreased slope stability and drove soil runoff. To alleviate soil loss and expand space for polycropping, various Mediterranean islanders implemented terracing regimes during the Early to Mid-Holocene (Bevan \& Conolly 2011). Such systems require intensive management, and episodic abandonment could result in the mass sediment transport that is evident in fluvial sedimentary records (Butzer 2005).

Globally, the Columbian exchange was a watershed in the ecology of islands, but in the Mediterranean - where the societies that initiated such contacts originated - there is much less evidence for such disruptions. Broodbank (2013), in fact, traced the origin of many textually recorded ecodynamic relationships to the initial Late Holocene and the aridification of the Sahara. Contact with the Americas and Oceania created significant changes in species composition, including the introduction of the tomato, maize, beans and peppers to the Mediterranean. Such introductions transformed human subsistence patterns and altered biophysical relationships from pollination dynamics to providing new niches for symbionts and parasites, but they did not traumatize already disturbance-adapted biotas in ways comparable to many other islands.

The historical ecology of the Mediterranean exemplifies how humans can, through short-term decision-making, create productive ecosystems in otherwise marginal environments. The deleterious impacts of hunter-gatherer-fishers and especially later Neolithic peoples - although partially 
mitigated by strategies such as fallowing, manuring and terracing - created productive anthropogenic ecosystems that were relatively resilient in their capacity to tolerate variation. Environmental change, including the gradual and variable establishment of Late Holocene climatic conditions, challenged human social organizations that were reliant on certain subsistence regimes. This suggests an exaggerated sensitivity of anthropogenic island ecologies to changing climate and ocean systems when compared to adjacent continental areas. This has implications beyond the Mediterranean for the maintenance of biodiversity, sustainability and sociopolitical stability.

\section{MARITIME HUNTER-GATHERER-FISHERS ON CALIFORNIA'S CHANNEL ISLANDS}

California's Channel Islands, divided into northern and southern groups, were home to Native Americans for at least 13,000 years. Some of the earliest islanders had sophisticated maritime capabilities focused on shellfishing, fishing and the hunting of birds and marine mammals (Erlandson et al. 2011). Unlike Pacific, Mediterranean and Caribbean islands occupied by ancient agriculturalists, Channel Islanders never introduced domesticates, save dogs, relying on a mix of marine and terrestrial foods, technological innovations and complex cultural adaptations to sustain large, sedentary populations. Recent Channel Islands research documents a variety of ways that foragers, often assumed to have a relatively light environmental footprint, transformed islands. Archaeological and palaeoecological data reveal patterns of human overexploitation and ancient management, providing insights for understanding and managing island ecosystems today.

The Channel Islands, located between 20 and $98 \mathrm{~km}$ off southern California's coast, range between 2.6 and $249 \mathrm{~km}^{2}$ in size. During the LGM, the northern islands (Anacapa, Santa Cruz, Santa Rosa and San Miguel) coalesced into one landmass, Santarosae, separated from the mainland by $c .8$ $\mathrm{km}$ (Reeder-Myers et al. 2015). The southern islands (Santa Barbara, San Clemente, San Nicolas and San Clemente) were larger during the LGM but were isolated by sizable water gaps. Isolation created unique island ecosystems and endemic and relict species with relatively impoverished terrestrial biodiversity. Exceptionally productive marine ecosystems supported diverse resources, however, including seaweeds, shellfish, fishes, sea mammals and birds.

Nearshore marine ecosystems were a major focus of Native American subsistence. Mussels (Mytilus californianus), abalone (Haliotis spp.), limpets (Lottia spp.), sea urchins (Strongylocentrotus spp.) and turban snails (Chlorostoma spp.) were especially important, and trans-Holocene studies show decreasing average sizes through time, linked to growing human predation pressure (Erlandson et al. 2008, 2011). Human depression of high-ranked shellfish species resulted in overexploitation and resource switching to lower-ranked taxa (Braje et al. 2007). Erlandson et al. (2005) argued that human depletion of local sea otter (Enhydra lutris) populations may have triggered trophic cascades beginning $c .7500 \mathrm{BP}$, releasing key shellfish resources and helping sustain viable shellfisheries for millennia (see Braje et al. 2009). The most dramatic impacts correlate with spikes in human populations and the formation of large coastal villages during the Late Holocene $(<3500 \mathrm{BP})$. Shellfish contributed an increasingly small percentage of dietary protein through time, but the overall intensity of harvest accelerated without evidence of extinctions or other long-term consequences.

Less is known about pre-Columbian human impacts on marine mammals, finfishes and seabirds. Fishing intensified significantly after the development of circular shell fishhooks c. 3500 years ago, and marine mammal hunting appears to have accelerated dramatically $c .1500 \mathrm{BP}$, roughly when the bow and arrow and plank canoe first appeared. These new technologies allowed islanders greater access to pinniped communities on offshore islets, as well as large pelagic fish.

Today, massive pinniped haul-outs located on or near ancient villages suggest that local distributions and behaviours of these animals have shifted since their release from ancient and historical hunting (Braje et al. 2011). Guadalupe fur seals (Arctocephalus tomnsendi) were the focus of native hunting during much of the Holocene (Rick et al. 2009), with elephant seals (Mirounga angustirostris) being rare in archaeological sites (Rick et al. 2011). Today, the situation is reversed, with abundant elephant seals and virtually no Guadalupe fur seals. The recent identification of sea mammal bone fragments from 9000-12,000-year-old sites show that elephant seals were hunted by some of the earliest islanders, who may have altered the structure of pinniped populations millennia ago. This suggests that multiple shifts in pinniped communities occurred on the Channel Islands - after initial human arrival, again during the colonial 18th- and 19th-century fur/oil trade and finally as a by-product of modern management and conservation.

The long-term ecodynamics of humans, finfishes and seabirds are more obscure. One clear example of prehistoric human-influenced extinction on the islands comes from a flightless duck (Chendytes lami) that was driven to extinction on the islands and mainland by c. $2400 \mathrm{BP}$ (Jones et al. 2008). Impacts to ground-nesting bird species were likely caused by the human introduction of dogs and foxes (Urocyon spp.) to the islands starting at least 6000 years ago (Rick 2013; Hofman et al. 2015). Preliminary studies also suggest that the average size of some prey fish species was significantly larger in the past than they are today (Braje et al. 2012, 2017).

We know less about the importance of terrestrial habitats for Channel Islander diets, but recent palaeobotanical research suggests that humans shaped and managed island landscapes for millennia. Fires occurred on the islands during the late Pleistocene and Holocene, and many of these may have been set by native peoples to expand grassland habitats that were rich in geophytes and other economically important plants (Gill 2013, 2015). Anderson et al. (2010) identified evidence for accelerated island burning during the human population 
increases of the Late Holocene (c. $3000 \mathrm{BP}$ ), which may be related to such landscape management systems.

By the mid-19th century, indigenous communities had been removed from the islands by Spanish colonizers, and the islands converted into commercial ranching, hunting and fishing outposts. Historically, the most dramatic changes swept across the islands with the introduction of numerous exotic herbivores, including horses (Equus spp.), cattle, sheep (Ovis aries), pigs, goats, rabbits and cervids such as elk (Cervus canadensis) and deer that caused widespread devegetation, soil erosion and changes in freshwater hydrology. Other exotic animals were also introduced, including domestic cats, rats and birds (e.g., turkeys (Meleagris spp.), chickens and quails (family: Odontophoridae)). Numerous exotic plants were also introduced, and local populations of pinnipeds and sea otters were devastated by the commercial fur trade. These changes transformed island ecosystems so extensively that it can be difficult to decode the pre-Columbian state and establish appropriate restoration baselines or benchmarks.

\section{CARIBBEAN ISLANDS IN FLUX}

The Caribbean has received less archaeological attention with regards to human impacts on island environments, particularly for landscape modification resulting from food production. Amerindian groups settled Trinidad as early as c. $8000 \mathrm{BP}$ (although it was in close proximity or partially connected to the Venezuelan coast in the Early Holocene), and Cuba, Hispaniola and Puerto Rico perhaps as early as c. 6000-5000 BP (Fitzpatrick 2015), introducing a suite of non-native plants and animals in a process that accelerated beginning c. 2000-1500 BP (Hofman et al. 2008; Giovas et al. 2012; Mickleburgh \& Pagán-Jiménez 2012).

If the degree of impact to Caribbean terrestrial environments is still poorly known, research has shown that humans began to effect native terrestrial and marine fauna in biologically impoverished and highly endemic island environments (Fitzpatrick \& Keegan 2007). These may have included sloths during the Archaic, whose extinctions seem independent of climatic changes, but not human arrival (Steadman et al. 2005). Other signs of human impacts involved the extinction or extirpation of reptile, mammal and bird species (Soto-Centeno \& Steadman 2015; Steadman \& Franklin 2015; Steadman et al. 2015). Several Ceramic Age archaeological assemblages show an early emphasis on, and then major decline of, rice rats (family: Cricetidae) and land crabs, with a commensurate increase in mollusc species (Newsom \& Wing 2004: 100, 102-104), suggesting overexploitation of terrestrial fauna and a move towards heavier reliance on marine foods. Larger marine mammals such as the manatee, the Caribbean monk seal (Monachus tropicalis) or migrating cetaceans seem not to have been a focus of prehistoric predation.

Zooarchaeological research in the northern Antilles shows changes in marine predation and consumption patterns, with carnivorous fishes such as groupers dominating earlier phases of occupation compared to herbivorous species such as surgeonfish (family: Acanthuridae) and parrotfish (subfamily: Scarinae). Nearshore taxa also become less dominant as pelagic fishes (e.g. jacks (family: Carangidae), flying fish (family: Exocoetidae) and tuna) increase (Newsom \& Wing 2004: 111112). There is also a general decline in the mean trophic level of reef fishes with a subsequent increase (or decrease) in the mean trophic level of inshore and pelagic fishes (Wing 2001: 112). In one case, the mean size of nearshore (reef) fishes declined between $c$. 1850-1280 and 1415-560 BP occupations, correlating with increased dependence on smaller fishes such as herrings (family: Clupeidae) and reduced mean trophic level. The shift towards more pelagic species and changes in the sizes of fish suggest that native peoples impacted nearshore environments, which may have resulted in an increased reliance on horticulture and new fishing technologies.

While some Caribbean evidence points to marine overexploitation, other data suggest that groups lived sustainably. Analysing fish assemblages from Anguilla, Carder et al. (2007) found no indication for overfishing over a period of 700-900 years. At a late Ceramic Age site on Nevis, a study of a large mollusc assemblage $(n=\geq 58,000)$ showed no signs of overharvest from c. 1200 to $500 \mathrm{BP}$, despite increased exploitation of some species (Poteate $e t$ al. 2015). Measurement of $>2700$ nerites (Nerita tessellata) from this collection showed a significant increase in shell size through time, despite elevated harvest levels (Giovas et al. 2013). Additional research is needed in order to examine the effects of native groups on Caribbean ecosystems, but these case studies suggest that even small human populations can affect fish populations and that mollusc harvesting may have compensated for declining fisheries (including sea turtles (superfamily: Chelonioidea)) in some areas.

If the level of impact on Caribbean biota prehistorically is still uncertain in many places, the arrival of Europeans was clearly disastrous to native groups and island ecologies. The 'Columbian Exchange' (Crosby 1972) - a transfer of people, pathogens, plants and animals between the Old and New Worlds - led to the deaths of hundreds of thousands of Amerindians, widespread land clearance for subsistence crops and trade such as coffee, sugarcane and tobacco and the decline or extirpation of numerous endemic species, including sea turtles and the Caribbean monk seal (see Fitzpatrick \& Keegan 2007). Competition by European powers for commercial and strategic control accelerated environmental impacts to such a degree that many Caribbean islands are ecological shadows of their pre-Columbian states.

\section{ISLANDS IN THE ANTHROPOCENE}

Around the world, archaeological and other records show that human transformation of island ecosystems has a deep history that often began with initial human arrival. In many cases, burning, landscape clearance and the introduction of exotic plants and animals drove significant ecological changes during the early stages of human settlement. Human 
Figure 2 Conceptual model depicting the influences of humans on island ecosystems after initial colonization and the epiphenomenal drivers of anthropogenic ecosystems (drafted by T.P. Leppard).

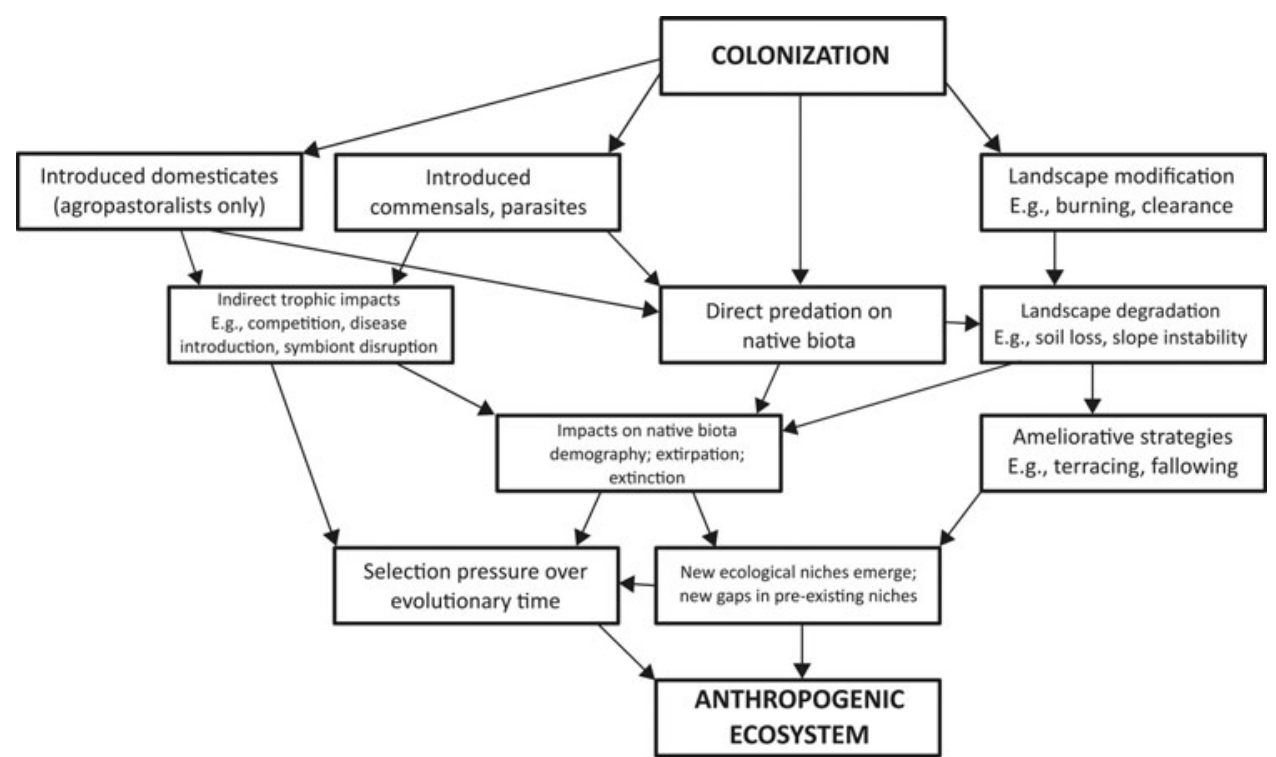

impacts accelerated as populations increased and economies intensified, often resulting in extinctions, soil erosion and increasingly anthropogenic landscapes.

The scale of human impacts on island ecosystems varied, however, based on many factors (Fig. 2). Hunter-gathererfisher colonizations on the Channel Islands and (initially) some Caribbean and Mediterranean islands seem to have left a relatively light footprint, with ecological changes that are often more difficult to discern in archaeological and palaeoecological records. Later settlement of islands by agricultural peoples in the Mediterranean, Caribbean and the remote Pacific resulted in relatively rapid landscape clearance, burning, biotic introductions, extinctions of endemic species and other changes that created anthropogenic island ecosystems that were actively managed by people for millennia.

Focusing on these broad patterns, however, obscures incredible variability in human ecodynamics on islands around the world. Hunter-gatherer-fishers on the Channel Islands introduced dogs, foxes, deer mice and possibly other organisms, burned scrublands to create favourable conditions for grasslands and geophytes for millennia, altered pinniped and shellfish populations and triggered trophic cascades in kelp ecosystems as much as 8000 years ago. Polynesian maritime agriculturalists colonized the Pacific and successfully managed their populations and subsistence strategies on some islands, but were less successful at avoiding ecological disaster on others. The scale of human impacts depended on a number of complex, intersecting variables, from island physiography to human subsistence strategies, population densities, technology, sociopolitical organization and human decision-making (see Kirch 2007). On Californian, Pacific, Caribbean and other islands, however, the impacts of indigenous peoples pale in comparison to those associated with historical Euro-American and Asian settlement and the introduction of many more exotic plant and animal species. This is the one pattern that may be universal - the rapid and transformative effects of colonial expansion and occupation. Whether islands were small or large, continental or oceanic, isolated or not, their colonization by Europeans and other groups and their integration into global economic systems resulted in the introduction of no-analogue ecological systems and devastatingly swift changes to island habitats.

Ultimately, this differential timing and scale of the human modification of island ecosystems poses one of the central challenges of historical ecology. Understanding long-term processes of human-island interactions can help reconstruct the evolution of island ecosystems, but creates a dilemma for conservation scientists: what are the preferred temporal and spatial baselines for restoration and management? Like all ecological communities, islands have been (and are) in a nearly constant state of flux (Graham 1988), although anthropogenic climate change is now accelerating the pace of change. For some, we should establish baselines at a prehuman colonization temporal scale; for others pre-European colonialization; and for others something in between. If the target time period is too shallow, long-term environmental disturbances may be overlooked, and we risk restoring ecosystems to already-degraded and no-analogue states. If the temporal target is too old, benchmarks may be unobtainable within current or future ecological states (Landres 1992).

Archaeological perspectives offer multi-scalar records of island ecological changes and view humans as integral to these processes. If conservation biology is to succeed over the longue durée, deep historical (archaeological) data offer critical records of long-term change and human ecodynamics. Historical data can identify a range of ecological states that once existed and provide multiple benchmarks to help guide conservation efforts. Deciding which temporal baselines, if any, are most appropriate is inherently political, driven by assessments of desired future conditions. We cannot rewind the clock to past ecological states, but deep historical perspectives may help us to create more practical and 
successful management plans. Our review suggests that there is no single or global solution, but that practical restoration choices will best be made by considering the implications of the deep time perspective for rebuilding ecosystems and resiliency in individual islands or archipelagos.

\section{ACKNOWLEDGEMENTS}

We thank the Foundation for Environmental Conservation for inviting this review, and John Cherry, Tim Rieth, the editors and three reviewers for their comments on earlier drafts.

\section{References}

Alcover, J.A., Sans, A. \& Palmer, M. (1998) The extent of extinctions of mammals on islands. Fournal of Biogeography 25: 913-918.

Allen, H.D. (2003) Response of past and present Mediterranean ecosystems to environmental change. Progress in Physical Geography 27: 359-377.

Anderson, A. (2009) The rat and the octopus: initial human colonization and the prehistoric introduction of domestic animals to Remote Oceania. Biological Invasions 11: 1503-1519.

Anderson, A., Chappell, J., Gagan, M. \& Grove, R. (2006) Prehistoric maritime migration in the Pacific islands: an hypothesis of ENSO forcing. The Holocene 16: 1-6.

Anderson, R.S., Starratt, S., Brunner Jass, R.M. \& Pinter, N. (2010) Fire and vegetation history on Santa Rosa Island, Channel Islands, and long-term environmental change in southern California. Fournal of Quaternary Science 25: 782-797.

Athens, J.S., Rieth, T.M. \& Dye, T.S. (2014) A palaeoenvironmental and archaeological model-based estimate for the colonisation of Hawai'i. American Antiquity 79:144-155.

Barnosky, A.D., Hadly, E.A., Gonzalez, P., Head, J., Polly, P.D., Lawing, A.M., Eronen, J.T., Ackerly, D.D., Alex, K., Biber, E., Blois, J., Brashares, J., Ceballos, G., Davis, E., Dietl, G.P., Dirzo, R., Doremus, H., Fortelius, M., Greene, H.W., Hellman, J., Hickler, T., Jackson, S.T., Kemp, M., Koch, P.L., Kremen, C., Lindsey, E.L., Looy, C., Marshall, C.R., Mendenhall, C., Mulch, A., Mychajliw, A.M., Nowak, C., Ramakrishnan, U., Schnitzler, J., Das Shrestha, K., Solari, K., Stegner, L., Allison Stegner, M., Chr. Stenseth, N., Wake, M.H. \& Zhang, Z. (2017) Merging paleobiology with conservation biology to guide the future of terrestrial ecosystems. Science 355: eaah4787.

Bevan, A. \& Conolly, J. (2011) Terraced fields and Mediterranean landscape structure: an analytical case study from Antikythera, Greece. Ecological Modelling 222: 1303-1314.

Bocquet-Appel, J.-P. (2011) When the world's population took off: the springboard of the Neolithic demographic transition. Science 333: 560-561.

Bover, P., Valenzuela, A., Torres, E., Cooper, A., Pons, J. \& Alcover, J.A. (2016). Closing the gap: new data on the last documented Myotragus and the first human evidence on Mallorca (Balearic Islands, Western Mediterranean Sea). The Holocene 26: 18871891.

Boivin, N., Zeder, M.A., Fuller, D.Q., Crowther, A., Larson, G., Erlandson, J.M., Denham, T. \& Petraglia, M.D. (2016) Ecological consequences of human niche construction: examining long-term anthropogenic shaping of global species distributions. Proceedings of the National Academy of Sciences 113: 6388-6396.
Braje, T.J. (2015) Earth systems, human agency, and the Anthropocene: planet earth in the human age. Fournal of Archaeological Research 23: 369-396.

Braje, T.J., Erlandson, J.M., Rick, T.C., Dayton, P.K. \& Hatch, M. (2009) Fishing from past to present: long-term continuity and resilience of red abalone fisheries on California's Northern Channel Islands. Ecological Applications 19: 906919.

Braje, T.J., Kennett, D.J., Erlandson, J.M. \& Culleton, B.J. (2007) Human impacts on nearshore shellfish taxa: a 7,000 year record from Santa Rosa Island, California. American Antiquity 72: 735756.

Braje, T.J. \& Rick, T.C. (2013) From forest fires to fisheries management: anthropology, conservation biology, and historical ecology. Evolutionary Anthropology 4: 116-121.

Braje, T.J., Rick, T.C. \& Erlandson, J.M. (2012) Rockfish in the longview: applied archaeology and conservation of Pacific red snapper (genus Sebastes) in southern California. In: Applied Zooarchaeology and Conservation Biology, eds. S. Wolverton \& R.L. Lyman, pp. 157-178. Tucson, AZ: University of Arizona Press.

Braje, T.J., Rick, T.C., Erlandson, J.M. \& DeLong, R.L. (2011) Resilience and reorganization: archaeology and historical ecology of California Channel Island marine mammals. In: Human Impacts on Seals, Sea Lions, and Sea Otters: Integrating Archaeology and Ecology in the Northeast Pacific, eds. T.J. Braje \& T.C. Rick, pp. 273-296. Berkeley, CA: University of California Press.

Braje, T.J., Rick, T.C., Szpak, P., Newsome, S.D., McCain, J.M., Elliot Smith, E.A., Glassow, M. \& Hamilton, S.L. (2017) Historical ecology and the conservation of large, hermaphroditic fishes in Pacific Coast kelp forest ecosystems. Science Advances 3: e1601759.

Broodbank, C. (2013). The Making of the Middle Sea: A History of the Mediterranean from the Beginning to the Emergence of the Classical World. London, UK: Thames and Hudson.

Broodbank, C. (2014) So... what? Does the paradigm currently want to budge so much? Fournal of Mediterranean Archaeology 27: 267-272.

Brose, U., Ostling, A., Harrison, K. \& Martinez, N.D. (2004) Unified spatial scaling of species and their trophic interactions. Nature 428 : 167-171.

Brumm, A., Jensen, G.M., van den Bergh, G.D., Morwood, M.J., Kurniawan, I., Aziz, F. \& Storey, M. (2010) Hominins on Flores, Indonesia by one million years ago. Nature 464: 748752.

Butzer, K. (2005) Environmental history in the Mediterranean world: cross-disciplinary investigation of cause-and-effect for degradation and soil erosion. Fournal of Archaeological Science 32: 1773-1800.

Carder, N., Reitz, E.J. \& Crock, J.G. (2007) Fish communities and populations during the post-Saladoid period (AD 600/800-1500), Anguilla, Lesser Antilles. Fournal of Archaeological Science 34: 588599.

Cherry, J.F. \& Leppard, T.P. (2017) Patterning and its causation in the pre-Neolithic colonization of the Mediterranean islands (Late Pleistocene to Early Holocene). Fournal of Island and Coastal Archaeology doi: 10.1080/15564894.2016.1276489.

Chynoweth, M.W., Litton, C.M., Lepczyk, C.A., Hess, S.C. \& Cordell, S. (2013) Biology and impacts of Pacific island invasive species. 9. Capra hircus, the feral goat (Mammalia: Bovidae). Pacific Science 67: 141-156. 
Clark, G., Anderson, A. \& Wright, D. (2006) Human colonization of the Palau Islands, western Micronesia. Fournal of Island \& Coastal Archaeology 1: 215-232.

Crosby, A.W. (1972) The Columbian Exchange: Biological Consequences of 1492. Westport, CT: Greenwood Publishing.

D'Antonio, C.M., Hughes, R.F. \& Tunison, J.T. (2011). Long-term impacts of invasive grasses and subsequent fire in seasonally dry Hawaiian woodlands. Ecological Applications 21: 1617-1628.

Dennell, R.W., Louys, J., O'Regan, H.J. \& Wilkinson, D.M. (2014) The origins and persistence of Homo floresiensis on Flores: biogeographical and ecological perspectives. Quaternary Science Reviems 96: 98-107.

Di Rita, F. \& Melis, R.T. (2013) The cultural landscape near the ancient city of Tharros (central West Sardinia): vegetation changes and human impact. Fournal of Archaeological Science 40: 42714282 .

Dye, T.S. \& Komori, E. (1992) A pre-censal population history of Hawai'i. New Zealand Fournal of Archaeology 14: 113-128.

Erlandson, J.M. (2010) Neptune's children: the origins and evolution of seafaring. In: The Global Origins and Development of Seafaring, eds. A. Anderson, J. Barrett \& K. Boyle, pp. 18-27. Cambridge, UK: Cambridge University Press.

Erlandson, J.M. \& Braje, T.J., eds. (2013) When humans dominated Earth: archeological perspectives on the Anthropocene. Anthropocene 4: 1-125.

Erlandson, J.M. \& Fitzpatrick, S.M. (2006) Oceans, islands, and coasts: current perspectives on the roles of the sea in human prehistory. Fournal of Island and Coastal Archaeology 1: 5-32.

Erlandson, J.M., Braje, T.J., Rick, T.C., Jew, N.P., Kennett, D.J., Dwyer, N., Ainis, A., Vellanoweth, R.L. \& Watts, J. (2011) 10,000 years of human predation and size changes in the owl limpets (Lottia gigantea) on San Miguel Island, California. Journal of Archaeological Science 38: 1127-1134.

Erlandson, J.M., Rick, T.C., Braje, T.J., Steinburg, A. \& Vellanoweth, R.L. (2008) Human impacts on ancient shellfish: a 10,000 year record from San Miguel Island, California. Fournal of Archaeological Science 35: 2144-2152.

Erlandson, J.M, Rick, T.C., Braje, T.J., Casperson, M., Culleton, B., Fulfrost, B., Garcia, T., Guthrie, D., Jew, N., Kennett, D., Moss, M.L., Reeder, L., Skinner, C., Watts, J. \& Willis, L. (2011) Paleoindian seafaring, maritime technologies, and coastal foraging on California's Channel Islands. Science 441: 1181-1185.

Erlandson, J.M., Rick, T.C., Estes, J.A., Graham, M.H., Braje, T.J. \& Vellanoweth, R.L. (2005) Sea otters, shellfish, and humans: 10,000 years of ecological interaction on San Miguel Island, California. In: Proceedings of the Sixth California Islands Conference, eds. D.K. Garcelon \& C.A. Schwemm, pp. 9-21. Arcata, CA: Institute for Wildlife Studies.

Field, J.S., Ladefoged, T.N. \& Kirch, P.V. (2011) Household expansion linked to agricultural intensification during emergence of Hawaiian archaic states. Proceedings of the National Academy of Sciences 108: 7327-7332.

Firth, R. (1967) Tikopia Ritual and Belief. London, UK: George Allen and Unwin.

Fitzpatrick, S.M. (2003) Early human burials in the western Pacific: evidence for c. 3000 year old occupation on Palau. Antiquity 77: 719-731.

Fitzpatrick, S.M. (2008) Maritime interregional interaction in Micronesia: deciphering multi-group contacts and exchange systems through time. Fournal of Anthropological Archaeology 27: 131-147.
Fitzpatrick, S.M. (2015) The Pre-Columbian Caribbean: colonization, population dispersal, and island adaptations. PaleoAmerica 1 : 305-331.

Fitzpatrick, S.M. \& Keegan, W.F. (2007) Human impacts and adaptations in the Caribbean Islands: an historical ecology approach. Earth and Environmental Science Transactions of the Royal Society of Edinburgh 98: 29-45.

Flannery, T.E, Kirch, P.V., Specht, J. \& Spriggs, M. (1988). Holocene mammal faunas from archaeological sites in island Melanesia. Archaeology in Oceania 23: 89-94.

Fujita, M., Yamasaki, S., Katagiri, C., Oshiro, I., Sano, K., Kurozumi, T, Sugawara, H., Kunikita, D., Matsuzaki, H., Kano, A., Okumura, T., Sone, T., Fujita, H., Kobayashi, S., Naruse, T., Kondo, M., Matsu'ura, S., Suwa, G. \& Kaifu, Y. (2016). Advanced maritime adaptation in the western Pacific coastal region extends back to 35,000-30,000 years before present. Proceedings of the National Academy of Sciences 113: 11184-11189.

Gill, K.M. (2013) Paleoethnobotanical investigations on the Channel Islands: current directions and theoretical considerations. In: California's Channel Islands: The Archaeology of HumanEnvironmental Interactions, eds. C. Jazwa \& J. Perry, pp. 113-136. Salt Lake City, UT: University of Utah Press.

Gill, K.M. (2015). Ancient Plant Use and the Importance of Geophytes among the Island Chumash of Santa Cruz Island, California. PhD dissertation, University of California, Santa Barbara.

Giovas, C.M., LeFebvre, M.J. \& Fitzpatrick, S.M. (2012) New records for prehistoric introduction of Neotropical mammals to the West Indies: evidence from Carriacou, Lesser Antilles. Fournal of Biogeography 39: 476-487.

Giovas, C.M., Clark, M., Fitzpatrick, S.M. \& Stone, J. (2013) Intensifying collection and size increase of the tessellated nerite snail (Nerita tessellata) at the Coconut Walk site, Nevis, northern Lesser Antilles, AD 890-1440. Fournal of Archaeological Science 40: 4024-4038.

Goodwin, I.D., Browning, S.A. \& Anderson, A.J. (2014) Climate windows for Polynesian voyaging to New Zealand and Easter Island. Proceedings of the National Academy of Sciences 111: 1471614721

Graham, R.W. (1988) The role of climate change in the design of biological preserves. Conservation Biology 2: 391-394.

Hofman, C.L., Bright, A. J., Hoogland, M.L.P. \& Keegan, W.F. (2008) Attractive ideas, desirable goods: examining the Late Ceramic Age relationships between Greater and Lesser Antillean societies. Fournal of Island and Coastal Archaeology 3: 1734.

Hofman, C.A., Rick, T.C., Hawkins, M.T.R., Funk, W.C., Ralls, K., Boser, C.L., Collins, P.W., Coonan, T., King, J.L., Morrison, S.A., Newsome, S.D., Sillett, T.S., Fleischer, R.C. \& Maldonado, J.E. (2015) Mitochondrial genomes suggest rapid evolution of dwarf California Channel Islands foxes (Urocyon littoralis). PLoS ONE 10: $\mathrm{e} 0118240$.

Irwin, G. (1994) The Prehistoric Exploration and Colonisation of the Pacific. Cambridge, UK: Cambridge University Press.

Jackson, S.T. \& Hobbs, R.J. (2009) Ecological restoration in the light of ecological history. Science 325: 567-569.

Johnson, C.N. Alroy, J. Beeton, N.J., Bird, M.I., Brook, B.W., Cooper, A., Gillespie, R. Herrando-Pérez, S., Jacobs, Z., Miller, G.H., Prideaux, G.J., Roberts, R.G., Rodríguez-Rey, M., Saltré, F., Turney, C.S.M. \& Bradshaw, C.J.A. (2016). What caused extinction of the Pleistocene megafauna of Sahul? Proceedings of the Royal Society B 283: 20152399. 
Jones, T.L., Porcasi, J.F., Erlandson, J.M., Dallas, Jr., H., Wake, T. \& Schwaderer, R. (2008) The protracted Holocene extinction of California's flightless sea duck (Chendytes lami) and its implications for the Pleistocene Overkill Hypothesis. Proceedings of the National Academy of Sciences 105: 4105-4410.

Jupiter, S., Mangubhai, S. \& Kingsford, R.T. (2014). Conservation of biodiversity in the Pacific islands of Oceania: challenges and opportunities. Pacific Conservation Biology 20: 206-220.

Kirch, P.V. (1996) Late Holocene human-induced modifications to a central Polynesian island ecosystem. Proceedings of the National Academy of Sciences 93: 5296-5300.

Kirch, P.V. (1997) Microcosmic histories: island perspectives on global change. American Anthropologist 99: 30-42.

Kirch, P.V. (2007) Hawaii as a model system for human ecodynamics. American Anthropologist 109: 8-26.

Kirch, P.V. (2010) How Chiefs Became Kings: Divine Kingship and the Rise of Archaic States in Ancient Hawai'i. Berkeley, CA: University of California Press.

Kirch, P.V. \& Rallu, J.-L. (2007) The Gromth and Collapse of Pacific Island Societies. Honolulu, HI: University of Hawai'i Press.

Knapp, A.B. (2013) The Archaeology of Cyprus: From Earliest Prehistory through the Bronze Age. Cambridge, UK: Cambridge University Press.

Kolb, M.J. (2006) The origins of monumental architecture in ancient Hawai'i. Current Anthropology 46: 657-664.

Ladefoged, T.N., Kirch, P.V., Gon, S.M., Chadwick, O.A., Hartshorn, A.S. \& Vitousek, P.M. (2009) Opportunities and constraints for intensive agriculture in the Hawaiian archipelago prior to European contact. Fournal of Archaeological Science 36: 2374-2383.

Landres, P. B. (1992) Temporal scale perspectives in managing biological diversity. Transactions of the North American Wildlife and Natural Resources Conferences 57: 292-307.

Leppard, T.P. (2014) Modeling the impacts of Mediterranean island colonization by archaic hominins: the likelihood of an insular Lower Palaeolithic. Fournal of Mediterranean Archaeology 27: 231254.

Leppard, T.P. \& Pilaar Birch, S.E. (2016). The insular ecology and palaeoenvironmental impacts of the domestic goat (Capra hircus) in Mediterranean Neolithization. In: Géoarchéologie des Iles de la Méditerranée, eds. M. Ghilardi, S. Fachard, L. Lespez, F. Leandri \& C. Bressy-Leandri, pp. 47-56. Paris, France: CNRS Editions Alpha.

Lewis, S.L. \& Maslin, M.A. (2015) Defining the Anthropocene. Nature 519: 171-180.

Lightfoot, K.G., Panich, L.M., Schneider, T.D. \& Gonzalez, S.L. (2013) European colonialism and the Anthropocene: a view from the Pacific Coast of North America. Anthropocene 4: 101-115.

Lotze, H.K., Erlandson, J.M., Hardt, M.J., Norris, R.D., Roy, K., Smith, T.D. \& Whitcraft, C.R. (2011) How do we know about the past? In: Shifting Baselines: The Past and the Future of Ocean Fisheries, eds. J.B.C. Jackson, K.E. Alexander, \& E. Sala, pp. 137161. Washington, DC: Island Press.

Mann, C.C. (2011) 1493: Uncovering the New World Columbus Created. New York, NY: Vintage Books.

Mickleburgh, H.L. \& Pagán-Jiménez, J.R. (2012) New insights into the consumption of maize and other food plants in the preColumbian Caribbean from starch grains trapped in human dental calculus. Fournal of Archaeological Science 39: 2468-2478.

Montenegro, A., Callaghan, R.C. \& Fitzpatrick, S.M. (2016). Using seafaring simulations and shortest-hop trajectories to model the prehistoric colonization of Remote Oceania. Proceedings of the National Academy of Sciences 113: 12685-12690.

Newsom, L.A. \& Wing, E.S. (2004) On Land and Sea: Native American Uses of Biological Resources in the West Indies. Tuscaloosa, AL: University of Alabama Press.

Palombo, M. (2008) Insularity and its effects. Quaternary International 182: 1-5.

Poteate, A.S., Fitzpatrick, S.M., Clark, M. \& Stone, J.H. (2015) Intensified mollusk exploitation on Nevis (West Indies) reveals $\sim$ six centuries of sustainable exploitation. Archaeological and Anthropological Sciences 7: 361-374.

Quintus, S., Allen, M.S. \& Ladefoged, T.N. (2016) In surplus and in scarcity: agricultural development, risk management, and political economy on Ofu Island, American Samoa. American Antiquity 81: 273-293.

Ramís, D. (2014) Early island exploitations: productive and subsistence strategies on the prehistoric Balearic Islands. In: The Cambridge Prehistory of the Bronze and Iron Age Mediterranean, eds. A.B. Knapp \& P. van Dommelen, pp. 44-56. Cambridge, UK: Cambridge University Press.

Reeder-Myers, L., Erlandson, J.M., Muhs, D.R. \& Rick, T.C. (2015) Sea level, paleogeography, and archaeology on California's Northern Channel Islands. Quaternary Research 83: 263-272.

Rick, T.C. (2013) Hunter-gatherers, endemic island mammals, and the historical ecology of California's Channel Islands. In: The Archaeology and Historical Ecology of Small Scale Economies, eds. T.V. Thompson \& J. Waggoner, Jr. pp. 41-64. Gainesville, FL: University of Florida Press.

Rick, T.C., DeLong, R.L., Erlandson, J.M., Braje, T.J., Jones, T.L., Arnold, J.E., Des Lauriers, M.R., Kennett, D.J., Vellanoweth, R.L. \& Wake, T.A. (2011) Where were the northern elephant seals? Holocene archaeology and biogeography of Mirounga angustirostris. Holocene 21: 1159-1166.

Rick, T.C., DeLong, R.L., Erlandson, J.M., Braje, T.J., Jones, T.L., Kennett, D.J., Wake, T.A. \& Walker, P.L. (2009) A trans-Holocene archaeological record of Guadalupe fur seals (Arctocephalus tomnsendi) on the California Coast. Marine Mammal Science 25: 487-502.

Rick, T.C. \& Erlandson, J.M. (2010) Archaeology meets marine ecology: the antiquity of maritime cultures and human impacts on marine fisheries and ecosystems. Annual Reviem of Marine Science 2: 231-251.

Rick, T.C., Kirch, P.V., Erlandson, J.M. \& Fitzpatrick, S.M. (2013) Archaeology, deep history, and the human transformation of island ecosystems. Anthropocene 4: 33-45.

Rick, T.C. \& Lockwood, R. (2013) Integrating paleobiology, archaeology, and history to inform biological conservation. Conservation Biology 27: 45-54.

Ruddiman, W.F., Ellis, E.C., Kaplan, J.O. \& Fuller, D.Q. (2015) Defining the epoch we live in. Science 348: 38-39.

Runnels, C. (2014) Early Palaeolithic on the Greek islands? Fournal of Mediterranean Archaeology 27: 211-230.

Sadori, L., Zanchetta, G. \& Giardini, M. (2008) Last Glacial to Holocene palaeoenvironmental evolution at Lago di Pergusa (Sicily, Southern Italy) as inferred by pollen, microcharcoal, and stable isotopes. Quaternary International 181: 4-14.

Saltré, F., Rodriguez-Rey, M., Brook, B.W., Johnson, C.N., Turney, C.S.M, Alroy, J., Cooper, A., Beeton, N., Bird, M.I., Fordham, D.A., Gillespie, R., Herrando-Perez, S., Jacobs, Z., Miller, G.H., Nogues-Bravo, D., Prideaux, G.J., Roberts, R.G. \& Bradshaw, C.J.A. (2016). Climate change not to blame for late Quaternary 
megafauna extinctions in Australia. Nature Communications 7: 10511.

Sampson, A. (1998) The Neolithic and Mesolithic occupation of the Cave of the Cyclope. Annual of the British School at Athens 93: $1-22$.

Sheppard, P.J., Chu, S. \& Walter, R. (2015) Re-dating Lapita movement into Remote Oceania. Fournal of Pacific Archaeology 6: $26-36$

Soto-Centeno, J.A. \& Steadman, D.W. (2015) Fossils reject climate change as the cause of extinction of Caribbean bats. Nature: Scientific Reports 5: 7971.

Steadman, D.W., Albury, N.A., Kakuk, B., Mead, J.I., SotoCenteno, J.A., Singleton, H.M. \& Franklin, J. (2015) Vertebrate community on an ice-age Caribbean island. Proceedings of the National Academy of Sciences 112: E5963-E5971.

Steadman, D.W. \& Franklin, J. (2015) Changes in a West Indian bird community since the Late Pleistocene. Fournal of Biogeography 42: $426-438$

Steadman, D.W. \& Martin, P.S. (2003) The late Quaternary extinction and future resurrection of birds on Pacific Islands. Earth-Science Reviems 61: 133-147.

Steadman, D.W., Martin, P.S., MacPhee, R.D.E., Jull, A.J.T., McDonald, H.G., Woods, C.A., Iturralde-Vinent, M. \& Hodgins, G.W.L. (2005) Asynchronous extinction of late Quaternary sloths on continents and islands. Proceedings of the National Academy of Sciences 102: 11763-11768.

Steadman, D.W. \& Martin, P.S. (2003) The late Quaternary extinction and future resurrection of birds on Pacific Islands. Earth-Science Reviems 61: 133-147.

Steadman, D.W., White, J.P. \& Allen, J. (1999) Prehistoric birds from New Ireland, Papua New Guinea: extinctions on a large Melanesian island. Proceedings of the National Academy of Sciences 96: 2563-2568.

Summerhayes, G.R., Field, J.H., Shaw, B. \& Gaffney, D. (2016) The archaeology of forest exploitation and change in the tropics during the Pleistocene: the case of Northern Sahul (Pleistocene New Guinea). Quaternary International doi.org/10.1016/j.quaint.2016.04.023.

Waters, C.N., Zalasiewicz, J., Summerhayes, C., Barnosky, A.D., Poirier, C., Galuszka, A., Cearreta, A., Edgeworth, M., Ellis, E.C., Ellis, M., Jeandel, C., Leinfelder, R., McNeill, J.R., deB. Richter, D., Steffen, W., Syvitski, J., Vidas, D., Wagreich, M., Williams, M., Zhisheng, A., Grinevald, J., Odada, E., Oreskes, N. \& Wolfe, A.P. (2016) The Anthropocene is functionally and stratigraphically distinct from the Holocene. Science 351: aad2622.

White, J.P. (2004) Where the wild things are: prehistoric animal translocation in the circum New Guinea archipelago. In: Voyages of Discovery: The Archaeology of Islands, ed. S.M. Fitzpatrick, pp. 147-164. Westport, CT: Praeger.

Wilmshurst, J.M., Hunt, T.L. \& Anderson, A. (2011) Highprecision radiocarbon dating shows recent and rapid initial human colonization of East Polynesia. Proceedings of the National Academy of Sciences 108: 1815-1820.

Wing, E.S. (2001) The sustainability of resources used by native Americans on four Caribbean islands. International fournal of Osteoarchaeology 11: 112-126.

Wolverton, S., Nagaoka, L. \& Rick, T.C. (2016) Applied Zooarchaeology: Five Case Studies. Clinton Corners, NY: Eliot Werner Publications.

Wroe, S., Field, J. \& Grayson, D.K. (2006) Megafaunal extinctions: climate, humans, and assumption. Trends in Ecology and Evolution 21: 61-62.

Zalasiewicz, J., Waters, C.N., Williams, M., Barnosky, A.D., Cearreta, A., Crutzen, P., Ellis, E., Ellis, M.A., Fairchild, I.J., Grinevald, J., Haff, P.K., Hajdas, I., Leinfelder, R., McNeill, J., Odada, E.O., Poirier, C., Richter, D., Steffen, W., Summerhayes, C., Syvitski, J.P.M., Vidas, D., Wagreich, M., Wing, S.L., Wolfe, A.P., An, Z. \& Oreskes, N. (2015) When did the Anthropocene begin? A mid-twentieth century boundary level is stratigraphically optimal. Quaternary International 383: 196-203. 